It must be concluded from the comments given that the word Indlandsisen (the Inland Ice, l'Indlandsis) has been restricted in meaning to such a degree that it makes most sense if confined to a place in Greenland, and it is still hoped that my first letter will just make things easier, not more complicated.

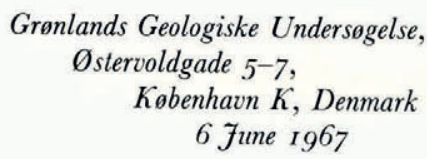

ANker WeIDick

REFERENCES Ahlmann, H. W. 1948. Glaciological research on the North Atlantic coasts. London, Royal Geographical Society.
(R.G.S. Research Series, No. I.)

Armstrong, T. E., and others. I967. About the use of the expression "Indlandsis": comments on Dr. Weidick's letter [by] T. [E.] Armstrong, B. [B.] Roberts and C. [W. M.] Swithinbank. Journal of Glaciology, Vol. 6, No. 48 ,
p. $95^{0}-5 \mathrm{I}$. Bugge, A., and others. 1960. Dansk-gronlandsk ordbog, [by] A. Bugge, K. Lynge, A. Fuglsang-Damgaard, F. Nielsen.
København, Ministeriet for Grønland.

Charlesworth, J. K. 1957. The Quaternary era, with special reference to its glaciation. London, Edward Arnold. 2 vols. Kleinschmidt, S. 1851. Grammatik der grönländischen Sprache mit theilweisem Einschluss des Labradordialects. Berlin,
G. Reimer Verlag.

Lliboutry, L. 1964-65. Traité de glaciologie. Paris, Masson et Cie. 2 vols.

Matthes, F. E. I 942 . Glaciers. (In Meinzer, O. E., ed. Hydrology. New York, McGraw-Hill, p. I49-219. (Physics of
the Earth, 9.))

Sharp, R. P. 1956. Glaciers in the Arctic. Arctic, Vol. 9, Nos. 1-2, p. 78-1 7 . Schultz-Lorentzen, C. W. 1927. Dictionary of the West Greenland Eskimo language. Meddelelser om Gronland,
Bd. 69. Schultz-Lorentzen, C. W. 1945. A grammar of the West Greenland language. Meddelelser om Gronland, Bd. 129,
Nr. 3.

SIR,

$$
\text { Non-earthquake origin of supraglacial debris on Martin River and Sioux Glaciers, Alaska }
$$

Tuthill (1966) has suggested that former earthquake-avalanching was the primary source of the debris on the lower part of Martin River Glacier. This appears unlikely for the following reasons:

I. Source areas for large-scale rock-slide avalanches are absent in the lower valley where the debris is located.

2. If avalanching occurred in the lower valley, lateral moraines and medial moraines on the glacier would have been covered. This is not the case.

3. If avalanching occurred in the narrow tributary glaciers, many individual avalanches would be required to account for the deposit. Only one obvious large deposit of this nature has been identified in recent photographs of the glacier (Fig. I).

4. A large avalanche deposit on any of the main tributary glaciers would cover other medial moraines present on the same branch. Only the deposit mentioned above appears to cover even one medial moraine.

5. Prior to 1964 several strong earthquakes with Richter magnitudes between 7.5 and $8+$ have occurred in the general vicinity of Martin River Glacier. The largest of the close seismic events are the 1899 earthquake at Yakutat, one in 1896 near Valdez and another in 1928 in the vicinity of Middleton Island (Post, 1965, fig. 3). If Tuthill's concept is correct, previous earthquakes in this seismically active region should have left plentiful evidence of such occurrences in the form of avalanche debris in transit between the source area and the terminus comparable to the large rock-slide avalanches which occurred during the 1964 Alaska earthquake (Post, in press).

Some idea of the time involved for ice to move from the point where the 1964 avalanches occurred to the terminus may be determined from the number and spacing of ogives found in the ice derived from the main tributary. 40 of these ogives were plotted. Divided into increments of ten, these are shown by arrows on Figure 2. If the ogives were formed annually and the glacier flow is uniform, the ice moved $7 \mathrm{~km}$. in this area in the past $40 \mathrm{yr}$. Air photographs indicate that between August 1964 and August 1965 ice in this tributary immediately above its juncture with the main glacier moved $260 \mathrm{~m}$. An annual movement of $200 \mathrm{~m}$. in the wider glacier where the ogives were mapped would thus appear to be in 
excellent agreement. These measurements indicate that it would take less than $400 \mathrm{yr}$. for the ice to move from the site of the 1964 avalanches to the terminal area of the glacier.

The i 964 rock-slide avalanches occurred near the firn line. The above flow-rate calculations indicate that debris from this general source area caused by earlier earthquakes during the past two or three centuries should be visible on the surface of the glacier. Figure $\mathrm{I}$ shows the glacier to be practically free of large deposits of debris near the terminus.

\section{Origin of debris}

The debris cover on the lower part of Martin River Glacier is not a single mass but it can be resolved into several discrete units except where vegetation conceals the material. Each of these units can be traced to one or more medial moraines and can be identified by distinctive differences in the material which appear as lighter or darker shades in air photographs (Fig. I).

On the main glacier most of these moraines are complexly folded. The folds are formed about $4 \mathrm{~km}$. below the point where the two easterly tributaries join. Here the glacier abruptly widens from $3 \cdot 0$ to

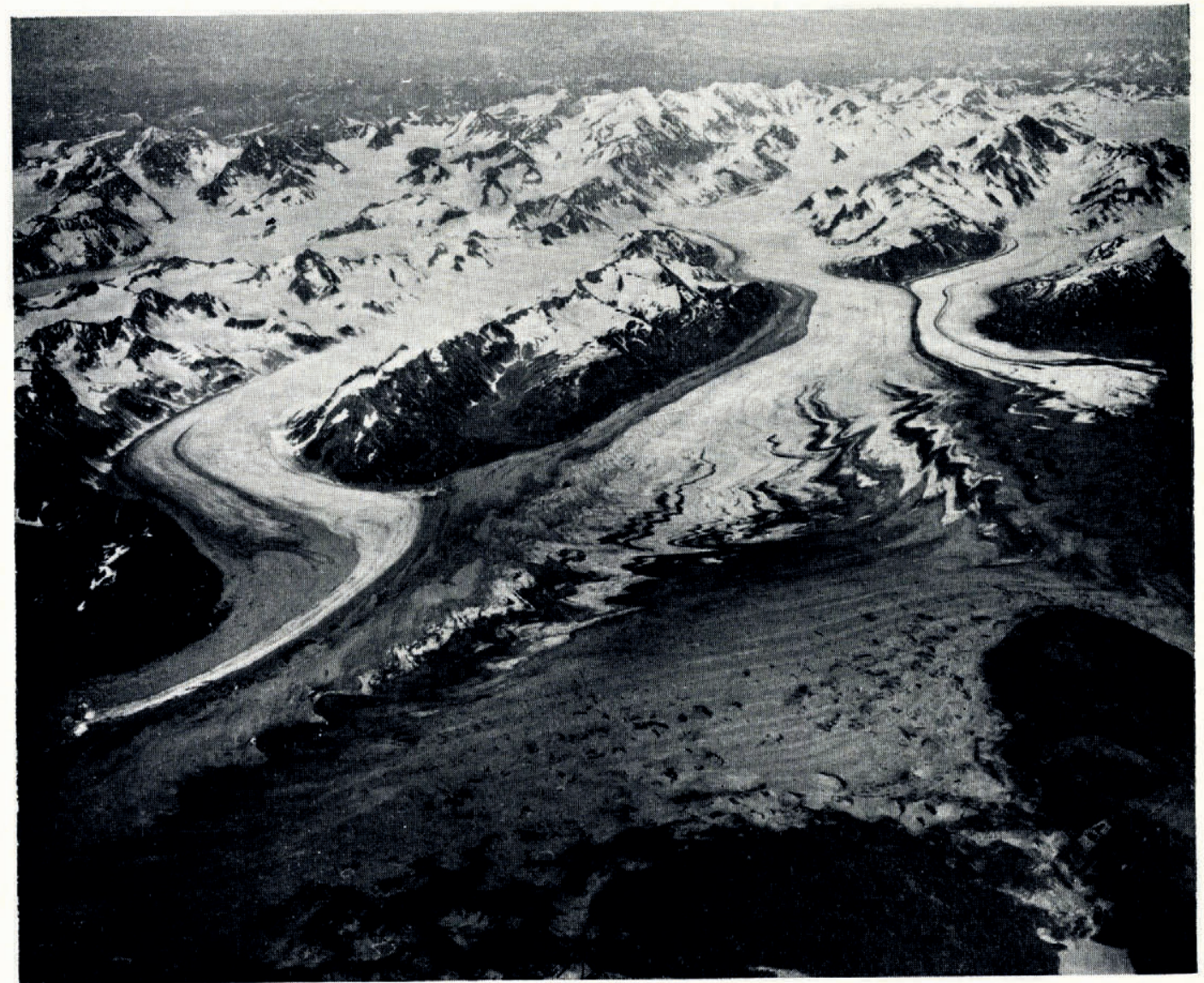

Fig. Martin River Glacier, viewed north-east from 6,ooo m. altitude. Folding of medial moraines takes place where the main glacier abruptly doubles its width. Compressive flow crowds the resulting folds into parallel ridges in the middle foreground where the ice stagnates against marginal hills. Ice on left flows towards Martin River; on right it flows towards the Kushtaka Glacier lobe. Note the absence of folds in the ice derived from the north branch (left). A large rockslide avalanche deposit can be seen on the north branch where it joins the main glacier. This was the most noteworthy avalanche deposit on the glacier prior to the 1964 earthquake. Above the area where the medial moraines are folded and compressed, the glacier is remarkably free from surface debris, evidence that large rock-slide avalanches on the glacier in recent centuries have been extremely rare. (Photograph by Austin Post, University of Washington, 26 August 1963) 


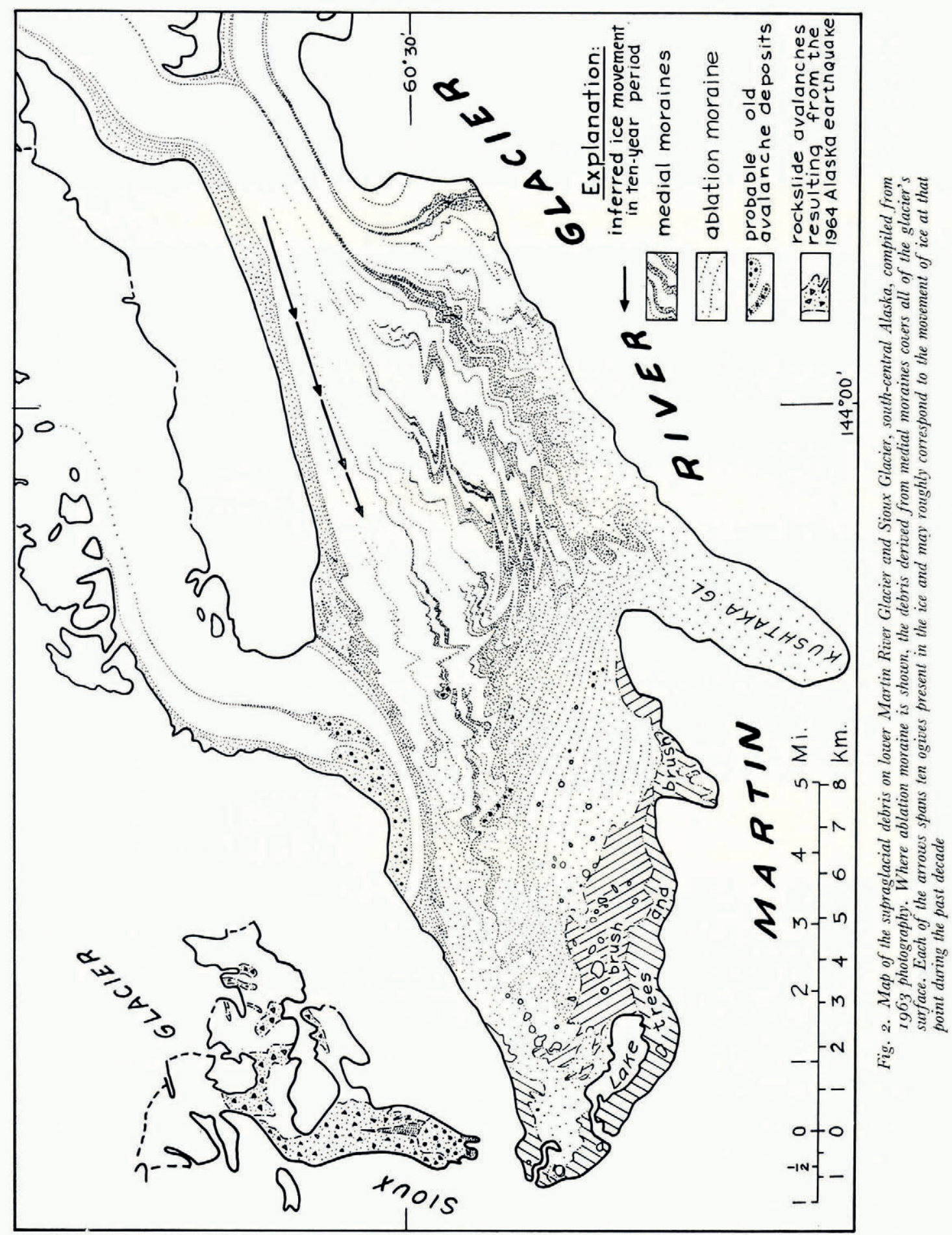


$6.5 \mathrm{~km}$. The folding is apparently associated with lateral spreading of the ice and associated decreased velocity. The main features of these folds are not random but can be traced across several medial moraines showing that the ice was deformed as a unit. Below the point where the folds are formed no further large-scale folding takes place, as shown by the unaffected ice derived from the north branch (Fig. I). However, compressive flow squeezes the existing folds together as the terminus is approached. In the south-eastern part of the glacier, one group of folds is deformed into long parallel ridges almost at rightangles to the direction of ice movement (Fig. I, center foreground).

\section{Sioux Glacier debris}

Photographs of this glacier taken before the 1964 earthquake display a rock-slide avalanche deposit

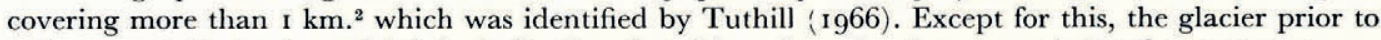
1964 was relatively clear of debris, indicating that this rock avalanche was an isolated occurrence.

\section{Conclusions}

The bulk of the debris on lower Martin River Glacier is derived from normal mass-wasting of slopes bordering the tributaries in the mountainous upper part of the glacier, which has been transported to the terminus first as lateral and then as medial moraines. The detritus is spread in the terminal area in part by folding of the medial moraines which occurs at a point where the glacier abruptly doubles its width. Small rock falls have contributed considerable material to these moraines but evidence of many large rock-slide avalanches prior to the 1964 earthquake is lacking.

For 100 yr. or more prior to the 1964 earthquake, only minor rock-slide avalanching had occurred on Martin River and Sioux Glaciers despite considerable strong earthquake activity in this general region. The rock-slide avalanches induced by the 1964 earthquake are apparently unprecedented in magnitude and form no basis for computing the contribution of earthquake-induced avalanching to supraglacial debris found near the terminus of many Alaskan glaciers.

U.S. Geological Survey,

Austin Post

\section{Tacoma, Washington, U.S.A.} I2 January 1967

\section{REFERENCES}

Post, A. S. 1965. Alaskan glaciers: recent observations in respect to the earthquake-advance theory. Science, Vol. 148, No. 3668, p. 366-68.

Post, A. S. In press. Effects on glaciers of the March 27. 1964 Alaska earthquake. U.S. Geological Survey. Professional Paper.

Tuthill, S. J. 1966. Earthquake origin of superglacial drift on the glaciers of the Martin River area, south-central Alaska. Journal of Glaciology, Vol. 6, No. 43, p. 83-88.

Sir,

Water-spout on Kaskawulsh Glacier, Yukon Territory*

While conducting field research on Kaskawulsh Glacier, Yukon Territory, Canada, an unusual phenomenon was observed which in this instance related to moulin formation. $30 \mathrm{~m}$. from the writers' position, at about i $1.00 \mathrm{hr}$. on 30 June 1966 , a vertical spout of water suddenly rose from the glacier surface. This was in the same area where Dewart (1966) observed several moulins.

The spout of water lasted 7-ro sec. and reached a maximum height of $4-5 \mathrm{~m}$. The only sound noted to accompany the phenomenon was the noise of rushing water; there was no sharp sound of fracturing ice. Immediate investigation of the site revealed that the water had issued from a vertical fissure 7-8 cm. wide and orientated perpendicular to glacier flow (Fig. I).

The site, which at this time of year was in the vicinity of the snow line, was covered with crusted snow to a depth of ${ }_{15}-20 \mathrm{~cm}$. The glacier ice at the fissure itself, however, was blown and washed bare for a distance of more than $\mathrm{I} \mathrm{m}$. along the length of the fissure and $25 \mathrm{~cm}$. on either side. This rectangular pattern of snow-free ice, along with the splatter pattern left by the falling water in the snow, suggests that in cross-section the fountain of water was tabular rather than columnar.

* Field research on the Kaskawulsh Glacier in the summer of 1966 was sponsored by the Icefield Ranges Research Project of the Arctic Institute of North America and the American Geographical Society. 